\title{
PHLOGOPITE AND ASSOCIATED MINERALS FROM PERMIAN MINETTES IN DEVON, SOUTH ENGLAND
}

\author{
ADRIAN P. JONES and JOSEPH V. SMITH
}

JONES, ADRIAN P. and SMITH, JOSEPH V., 1985: Phlogopite and associated minerals from Permian minettes in Devon, South England. Bull. Geol. Soc. Finland 57, Part 1-2, 89-102.

Electron-microprobe analyses were made of mica, clinopyroxene, alkali feldspar, Fe-Ti exides and apatite in Permian minettes from Hannaborough Quarry, Killerton Park and Loxbeare Farm, south Devon, England. Although these mica-lamprophyres contain various mineral assemblages and have undergone alteration, the compositions of unaltered minerals are similar to those of the Navajo minettes whose peridotite inclusions indicate an origin in the upper mantle. Micas from the Devon minettes evolved from $\mathrm{Mg}$-rich fluorphlogopites (FeO 3 wt. \%, $\mathrm{TiO}_{2} 2, \mathrm{Cr}_{2} \mathrm{O}_{3}$ 1.5, $\mathrm{NiO} 0.3, \mathrm{BaO} 0.3, \mathrm{~F}$ 4) to micas richer in $\mathrm{FeO}(10)$, $\mathrm{BaO}(0.8-2)$ and $\mathrm{TiO}_{2}(3-4)$. Diopside phenocrysts have cores low in $\mathrm{TiO}_{2}$ $(<0.3), \mathrm{FeO}(4-5)$ and $\mathrm{Na}_{2} \mathrm{O}(\sim 0.4)$. Alkali-feldspar laths from Killerton Park and Loxbeare Farm (mostly $\mathrm{Ab}_{20} \mathrm{An}_{5} \mathrm{Or}_{75}-\mathrm{Ab}_{29} \mathrm{An}_{7} \mathrm{Or}_{64}$ ) are rich in $\mathrm{BaO}$ $(0.4-1.7$ wt. $\%)$ and $\mathrm{SrO}(0.4-1.1)$. Hannaborough feldspars are partly albitized. Fluorapatite has light-REE enrichment $\left(0.5-1.4\right.$ wt. $\left.\% \mathrm{RE}_{2} \mathrm{O}_{3}\right)$ similar to apatite phenocrysts from the Navajo and Pendennis minettes; SrO is unexceptional $(0.6-1.3$ wt. $\%)$. Fe-Ti-oxides consist of $\mathrm{Ti}, \mathrm{Mg}, \mathrm{Al}$-magnetites largely altered to haematite and goethite-like minerals. Rare ilmenite has $6 \mathrm{wt} . \% \mathrm{MgO}$ which lies in the range of $5-23 \mathrm{wt} . \%$ for ilmenite from kimberlites; however the $2.9 \mathrm{wt} . \%$ $\mathrm{Al}_{2} \mathrm{O}_{3}$ is greater than the $0.8 \mathrm{wt} . \%$ maximum for kimberlitic ilmenites. In spite of the general similarities between the minerals from the Devon and Navajo minettes, the micas and apatites indicate a higher fluorine content in the former rocks.

Key words: minette, mica, pyroxene, feldspar, magnetite, apatite, Devon.

Adrian P. Jones: Division of Geological and Planetary Sciences, California Institute of Technology, Pasadena, California 91125, U.S.A.

Joseph V. Smith: Department of the Geophysical Sciences, The University of Chicago, Chicago, Illinois 60637, U.S.A.

\section{Introduction}

Petrogenetic interpretation of the lamprophyres requires detailed petrographic and chemical studies to augment the work of Velde (1969), Nemec (1972), Ehrenberg (1977), Bac- hinski and Scott (1979), Luhr and Carmichael (1981) and Hall (1982). Minettes are often geographically located near granites (Rock 1977), and there is growing evidence that the parent magmas of at least some minettes were generated in the upper mantle (Bachinski and Scott 1979; 
Roden 1981; Ehrenberg 1982; Jones and Smith 1983). Contamination and chemical alteration have affected the bulk composition of minettes, and it is essential to examine the textures and chemical profiles of the constituent minerals. This is part of a comprehensive study of the mineral chemistry of lamprophyres which began with a study of the Agathla Peak and The Thumb minettes of the Navajo volcanic field (Jones and Smith 1983). Mica compositions for Czechoslovakian lamprophyres will be reported by Schulze, Smith and Nemec. In this study, we are following the practice of the late Th. G. Sahama, whose studies of alkaline volcanic rocks provide an enduring testament to his memory. J. V. Smith wishes to record his gratitude for the opportunity to collaborate on the complex nepheline-kalsilite mineral assemblages from Central African volcanoes. It was always a great pleasure to receive a cheerful letter from, and occasionally meet with, such a smiling »teddy-bear.»

The present minettes were collected by APJ from sporadic outcrops in well-vegetated hilly farmland near Exeter in southwest England. They belong to a group of potassic extrusive and intrusive rocks of Permian age which were known as the »Exeter Lavas.» Tidmarsh (1932) reviewed the literature and correlated several local basalts, andesites, minettes and kersantites from detailed petrography and limited chemical analyses. He described devitrified glass-bearing leucite-minette from Loxbeare, and correctly identified the mica as phlogopite rich in $\mathrm{Cr}_{2} \mathrm{O}_{3}$ and $\mathrm{F}$. Velde (1971) re-identified the feldspathoid as analcime; note that both leucite and analcime have been found in minettes (e.g. Luhr and Carmichael 1981; Jones and Smith 1983). Knill (1969) described the intrusive nature of several of the minettes, reviewed the earlier literature, and gave a comprehensive guide to the status of remaining exposures, many of which are in small abandoned quarries, now becoming overgrown. Knill compared the K-rich igneous suite to the Navajo and Hopi volcanic fields in the U.S.A., and preferred an origin through assimilation of nearby Dartmoor (and related) granite by differentiated olivine basalt. Knill also remarked on the anomalously high $\mathrm{BaO}$ and $\mathrm{P}_{2} \mathrm{O}_{5}$, which are now known to be features of other mantle-derived minettes. Cosgrove (1972) gave whole rock analyses for minettes from the same localities reported here and suggested an origin by partial melting of subducted oceanic crust.

Hannaborough Quarry. Sample 8285 was collected from the same small quarry (Grid Reference SS 530 030) listed by Knill (1969, p. 125 ) and illustrated in the Regional Guidebook (Edmonds et al. 1968). In hand specimen it is reddened and leucocratic, with recognizable quartz fragments. Thin sections show prominent mica plates with pale cores and darker rims that are pleochroic from pale brown, through yellow brown to reddish brown. The micas are set in a groundmass of flow-aligned feldspar laths containing patches of red-brown ferruginous material after original mafic minerals and carbonate pseudomorphs after clinopyroxene phenocrysts. Small euhedral apatites, some with clouded cores, are quite common. Several quartz xenocrysts show irregular reaction mantles with a granophyric texture towards the groundmass. Knill (1969) reported dolomite and siderite pseudomorphs after olivine phenocrysts (average size $0.7 \mathrm{~mm}$ ), and distinguished both orthoclase and plagioclase (albite-oligoclase) in the groundmass. We found neither fresh olivine nor unambiguous pseudomorphs distinct from replaced clinopyroxene.

Killerton Park. Specimens of two minette variants described by Knill (1969) were collected. (a) »biotite-apatite-minette» from a track at G.R. SS 977002 and (b) »augitebiotite-minette» from a small quarry at G.R. SS 975 004. According to Knill (1969, p. 124), xenoliths of type (a) occur in type (b).

(a) »Biotite-apatite-minette» $(8286,8287)$; hand specimens show phenocrysts of dark mica and clinopyroxene set in a fine-grained pale- 
grey groundmass with further mica and recognizable clear apatite prisms (to $0.2 \mathrm{~mm}$ long). Thin sections show euhedral clinopyroxene phenocrysts, largely replaced by secondary carbonates, and dark mica plates set in a groundmass of alkali feldspar, mica and apatite. Apatite occurs as euhedral stubby prisms and accounts for several percent of the mode. A few euhedral pseudomorphs of carbonate could be after original olivine, though no fresh olivine was encountered with the electron probe. Additional alteration minerals include pale green ?epidote, usually in association with pseudomorphs after clinopyroxene.

(b) »Augite-biotite-minette» $(8288,8289$, 8290); hand specimens are similar to (a) above, but show somewhat more abundant mica and clinopyroxene. Thin sections show numerous euhedral clinopyroxene and mica phenocrysts set in a fesh trachytic groundmass of alkali feldspar, further mica and apatite. The mica is pleochroic from pale brown through yellow brown to orange in 8288 , but redder in 8289 and 8290 ; mica also occurs as poikilitic grains in a feldspar-rich xenolith, which deflects the flowaligned groundmass feldspar in 8288. Small patches of feldspar appear as radiating clusters in the groundmass, and a few large feldspars have irregular outlines and are probably xenocrysts. Several carbonate-rich patches have rounded outlines and could represent vesicle infillings rather than pseudomorphs after original phenocrysts. Groundmass textures are freshest in 8289 and 8290. Quartz xenocrysts are rare, but occur in 8290 where they are mantled by vaguely concentric reaction zones rich in alkali feldspar. Opaque Fe-Ti oxides occur as rounded grains included in mica phenocrysts and as separate grains in the groundmass, where they have not been secondarily altered to red ferruginous material. Sample 8290 is representative of these minettes in general, and has the following approximate modal components; clinopyroxene phenocrysts, including replacement by carbonates etc. $(15 \%)$, mica phenocrysts and groundmass $(15 \%)$, feldspar groundmass $(50-60 \%)$, apatite $(2-3 \%)$, Fe-Ti oxides $(5 \%)$, xenocrystal quartz $(<1 \%)$.

Loxbeare Farm. Sample 8290 was collected from a small quarry, located in a sketch map by Tidmarsh (1932, p. 715), just northwest (100 m) of Holmeade farm at G.R. AA 123 456. The specimen is a pale grey angular fragment collected from a heterogeneous volcanic breccia, that is itself most similar to the breccia matrix. Small quartz xenocrysts and dark shiny mica plates are readily visible against a feldspathic groundmass. Thin sections show abundant phenocrysts of mica, several with kink-banding, and quartz xenocrysts set in a fine-grained feldspar-rich groundmass. Closely-spaced colour bands in the finest-grained portions of the groundmass appear to be devitrified glass. A second generation of small mica microphenocrysts accentuates the flow banded nature of the groundmass, and common small $(<0.2 \mathrm{~mm})$ colorless quartz/alkali feldspar »eyes» in the groundmass resemble altered leucite. Fresh leucite was not encountered, despite a careful search with the electron probe, although unidentified and variable K-rich aluminosilicate material in the »eyes» with low analytical totals $(85-90 \%)$ may be an alteration product after leucite. The specimen is otherwise similar to a loose boulder of leucite-minette described by Tidmarsh (1932, p. 755). Velde (1971) found only analcime in different samples, some of which contained fresh olivine $\left(\mathrm{Fo}_{85}\right)$.

\section{Analytical procedures}

All analyses were made with an ARLEMX-SM electron microprobe. Both energy dispersive (EDS) and wavelength spectrometer (WDS) techniques were used and routine ZAF corrections were made with the Reed-Ware procedure (EDS) and MAGIC program (WDS) as modified by I. M. Steele. EDS analyses were made at $15 \mathrm{kV}, 0.04 \mu \mathrm{A}$ and most WDS analy- 
ses at $15 \mathrm{kV}, 0.1 \mu \mathrm{A}$ using a beam focused to less than $5 \mu \mathrm{m}$ diameter. A defocused beam $(5-15 \mu \mathrm{m})$ was used for mica analyses. Typical standards were synthetic diopside glass $(\mathrm{Ca}$, $\mathrm{Mg}, \mathrm{Si}$ ), chromium oxide (Cr), Sr-anorthite (Sr), natural rutile (Ti), Asbestos microcline (K, $\mathrm{Al}$ ), Mn-hortonolite (Mn, Fe), Amelia albite $(\mathrm{Na})$, barite $(\mathrm{Ba})$, nickel oxide $(\mathrm{Ni})$, fluorite $(\mathrm{F})$ and $\mathrm{Cl}$-apatite $(\mathrm{Cl}, \mathrm{P})$. Special WDS analyses for selected REE and $\mathrm{Y}$ in apatite at $25 \mathrm{kV}$ and $1.0 \mu \mathrm{A}$ used REE-doped synthetic silicate glass standards as in Exley and Smith (1982). EDS analyses are rounded off to one decimal place, and are averages of at least two determinations. The accuracy $(1 \sigma)$ is 1 to $5 \mathrm{wt} . \%$ of the amount present for major elements, and the detection level is 0.1 to $0.2 \mathrm{wt} . \%$ for EDS analyses and
0.01 to 0.03 wt. $\%$ for WDS analyses. Fluorine is an exception because of the low sensitivity and large correction factors; the precision is near 0.1 wt. \% for WDS analyses.

\section{MINERAL CHEMISTRY}

This section gives the prominent chemical characteristics and crystallization trends of the major minerals in the Devon minettes. A combination of textural and chemical information allowed distinction of primary and secondary features.

Mica. Figs. 1-4 show selected chemical trends for the analyses in Table 1. Many of the phlogopites from the Devon minettes show

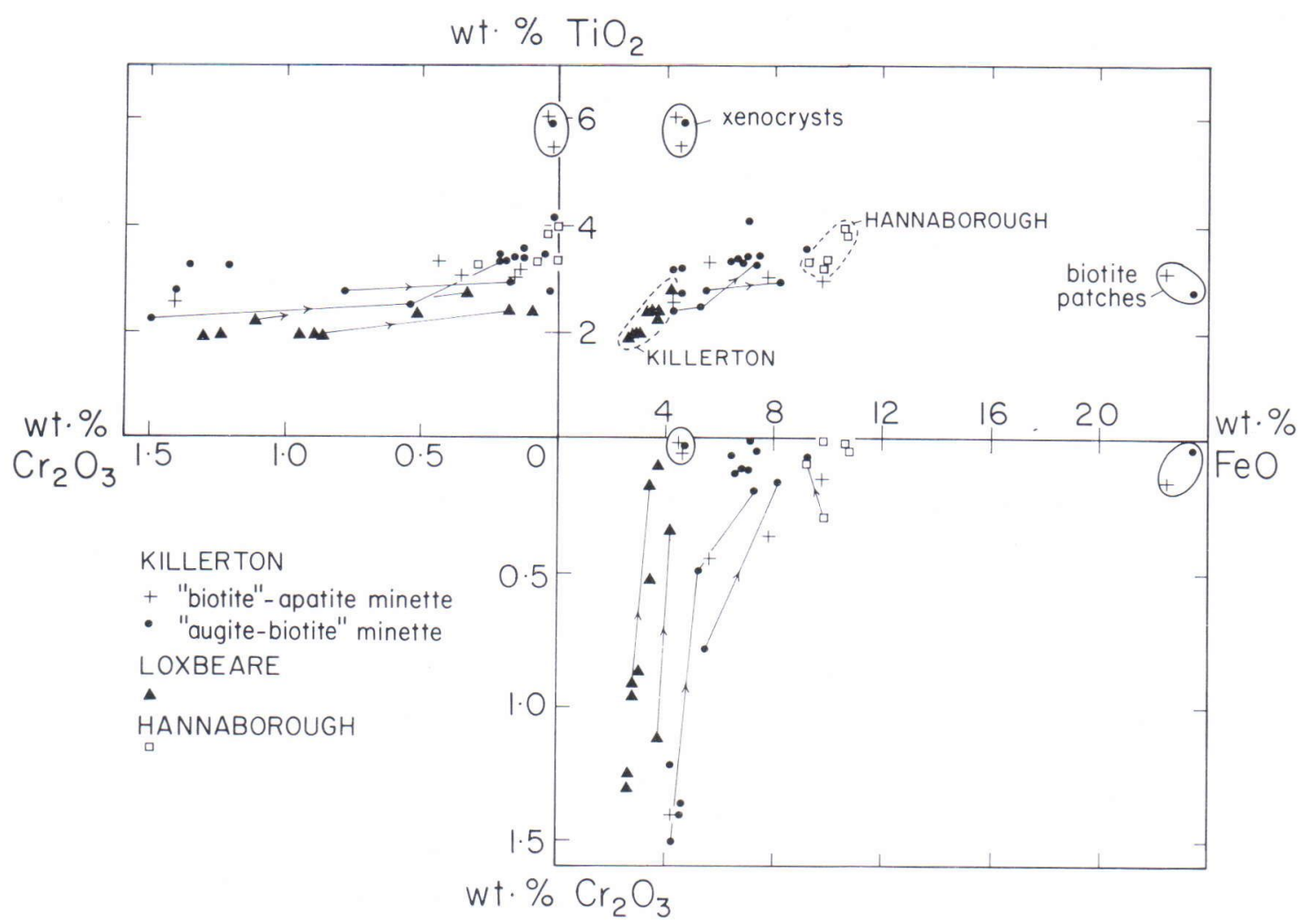

Fig. 1. Two-dimensional unfolding of the three-dimensional relation between $\mathrm{Cr}_{2} \mathrm{O}_{3}, \mathrm{TiO}_{2}$ and total iron (as $\mathrm{FeO}$ ) in micas. Core-rim relations are shown by arrows. 
overall trends of decreasing $\mathrm{Cr}_{2} \mathrm{O}_{3}$ and $\mathrm{NiO}$ as total iron, $\mathrm{TiO}_{2}$ and $\mathrm{BaO}$ increase. However, two groups of micas from Killerton deviate from the main trend of $\mathrm{TiO}_{2}$ vs. $\mathrm{FeO}$ (Fig. 1). The iron-rich ones with 24 wt. \% FeO (Table 1, anals. 9(r?) and 12(c?)) occur as patches in phlogopite grains. Because biotite 9(r?) has similar minor elements $(\mathrm{Cr}, \mathrm{Ti}, \mathrm{Ni}, \mathrm{Ba})$ to the associated phlogopite $9(\mathrm{c})$, it is suggested that the biotite results from alteration rather than simple crystal-liquid fractionation. Three phlogopites from Killerton with high $\mathrm{TiO}_{2}$ (5-6 wt. \%), low $\mathrm{FeO}(\sim 4.5$ wt. \%), and low $\mathrm{NiO}$, also deviate from the main trend. Two occur in the groundmass and the third is an irregular grain containing a biotite core(?). Such phlogopites with high $\mathrm{TiO}_{2}$ and low $\mathrm{FeO}$ have not been found in other minettes, and these three Killerton phlogopites are believed to be xenocrysts. Phlogopites with similar, but not quite

Table 1. Mica analyses.

\begin{tabular}{|c|c|c|c|c|c|c|c|c|c|c|c|c|}
\hline & \multicolumn{5}{|c|}{ Hannaborough } & \multicolumn{7}{|c|}{ Killerton Park »biotite-apatite» minette } \\
\hline & $1(\mathrm{c})$ & $1(\mathrm{r})$ & $2(c)$ & $2(r)$ & $3(c)$ & $4(\mathrm{~g}) \dagger$ & $5(\mathrm{~g}) \dagger$ & $6(c)$ & $7(\mathrm{c})$ & $8(3)$ & $9(c)$ & $* 9(r ?)$ \\
\hline $\mathrm{SiO}_{2}$ & 38.7 & 38.1 & 38.5 & 38.2 & 36.9 & 40.0 & 40.2 & 38.7 & 38.6 & 36.0 & 36.7 & 29.6 \\
\hline $\mathrm{TiO}_{2}$ & 3.19 & 3.30 & 3.81 & 3.96 & 3.38 & 5.48 & 6.00 & 3.33 & 3.18 & 2.57 & 2.82 & 3.05 \\
\hline $\mathrm{Al}_{2} \mathrm{O}_{3}$ & 14.3 & 14.7 & 15.8 & 14.6 & 14.1 & 10.8 & 11.1 & 13.7 & 13.8 & 14.2 & 12.6 & 12.2 \\
\hline $\mathrm{Cr}_{2} \mathrm{O}_{3}$ & 0.29 & 0.08 & 0.04 & 0.01 & 0.00 & 0.01 & 0.05 & 0.44 & 0.36 & 1.41 & 0.16 & 0.16 \\
\hline $\mathrm{FeO}_{\mathrm{T}}$ & 9.81 & 9.28 & 10.7 & 10.6 & 9.95 & 4.48 & 4.31 & 5.52 & 7.75 & 4.26 & 9.16 & 22.5 \\
\hline $\mathrm{MnO}$ & 0.05 & 0.07 & 0.04 & 0.08 & 0.03 & 0.10 & 0.10 & 0.09 & 0.09 & 0.03 & 0.05 & 0.15 \\
\hline $\mathrm{MgO}$ & 18.1 & 16.2 & 15.5 & 17.1 & 17.9 & 23.0 & 19.8 & 21.9 & 20.5 & 22.4 & 20.7 & 16.0 \\
\hline $\mathrm{NiO}$ & 0.03 & 0.00 & 0.00 & 0.08 & 0.00 & 0.02 & 0.00 & 0.21 & 0.22 & 0.37 & 0.19 & 0.09 \\
\hline $\mathrm{CaO}$ & 0.15 & 0.14 & 0.09 & 0.17 & 0.17 & 0.17 & 0.17 & 0.12 & 0.08 & 0.06 & 0.12 & 0.11 \\
\hline $\mathrm{BaO}$ & 1.52 & 1.54 & 0.17 & 0.16 & 1.88 & 0.11 & 0.28 & 0.39 & 0.41 & 0.38 & 0.41 & 0.74 \\
\hline $\mathrm{Na}_{2} \mathrm{O}$ & 0.51 & 0.68 & 0.50 & 0.44 & 1.46 & 0.58 & 0.58 & 0.46 & 0.49 & 0.40 & 0.47 & 0.56 \\
\hline $\mathrm{K}_{2} \mathrm{O}$ & 8.28 & 9.49 & 8.60 & 8.42 & 7.83 & 8.43 & 8.68 & 10.0 & 10.1 & 10.7 & 9.28 & 8.34 \\
\hline $\mathrm{F}$ & 2.00 & 2.57 & 2.09 & 1.71 & 2.36 & 5.04 & 4.83 & 4.78 & 3.47 & 2.70 & 3.19 & 3.20 \\
\hline $\mathrm{Cl}$ & 0.13 & 0.13 & 0.29 & 0.23 & 0.18 & 0.05 & 0.07 & n.a. & n.a. & n.a. & n.a. & n.a. \\
\hline \multirow[t]{3}{*}{ Sum } & 96.19 & 95.17 & 95.18 & 94.99 & 95.11 & 96.14 & 94.12 & 97.63 & 97.58 & 94.34 & 94.51 & 95.35 \\
\hline & \multicolumn{5}{|c|}{ Killerton Park »augite-biotite» minette } & \multicolumn{2}{|c|}{ Loxbeare } & & & & & \\
\hline & $10(\mathrm{~g})$ & $11(c)$ & $11(r)$ & *12(c?) & $12(r) \dagger$ & 13(c) & $13(\mathrm{r})$ & $14(c)$ & 14(r) & $15(\mathrm{~g})$ & & \\
\hline $\mathrm{SiO}_{2}$ & 37.5 & 39.6 & 39.0 & 30.2 & 38.4 & 38.7 & 39.4 & 39.6 & 39.6 & 39.4 & & \\
\hline $\mathrm{TiO}_{2}$ & 4.17 & 2.70 & 3.12 & 2.61 & 5.78 & 2.17 & 2.67 & 1.97 & 2.44 & 1.92 & & \\
\hline $\mathrm{Al}_{2} \mathrm{O}_{3}$ & 14.6 & 11.8 & 13.0 & 11.3 & 13.0 & 14.8 & 13.8 & 13.7 & 13.2 & 13.6 & & \\
\hline $\mathrm{Cr}_{2} \mathrm{O}_{3}$ & 0.01 & 1.41 & 1.32 & 0.03 & 0.03 & 1.11 & 0.33 & 0.89 & 0.18 & 1.92 & & \\
\hline $\mathrm{FeO}_{\mathrm{T}}$ & 7.08 & 4.45 & 4.37 & 23.4 & 4.44 & 3.72 & 4.15 & 2.84 & 3.46 & 2.64 & & \\
\hline $\mathrm{MnO}$ & 0.04 & 0.04 & 0.02 & 0.07 & 0.06 & 0.05 & 0.02 & 0.01 & 0.02 & 0.01 & & \\
\hline $\mathrm{MgO}$ & 20.0 & 22.5 & 22.0 & 17.2 & 20.7 & 22.4 & 23.0 & 23.8 & 23.8 & 23.9 & & \\
\hline $\mathrm{NiO}$ & 0.00 & 0.34 & 0.26 & 0.10 & 0.00 & 0.13 & 0.17 & 0.27 & 0.12 & 0.20 & & \\
\hline $\mathrm{CaO}$ & 0.18 & 0.24 & 0.27 & 0.15 & 0.08 & 0.14 & 0.18 & 0.11 & 0.15 & 0.11 & & \\
\hline $\mathrm{BaO}$ & 0.86 & 0.41 & 0.50 & 0.46 & 0.33 & 0.69 & 0.70 & 0.32 & 0.56 & 0.29 & & \\
\hline $\mathrm{Na}_{2} \mathrm{O}$ & 0.47 & 0.46 & 0.32 & 0.49 & 0.53 & 0.20 & 0.16 & 0.07 & 0.08 & 0.03 & & \\
\hline $\mathrm{K}_{2} \mathrm{O}$ & 9.12 & 9.93 & 9.03 & 7.03 & 9.40 & 8.91 & 8.82 & 10.3 & 9.85 & 9.87 & & \\
\hline $\mathrm{F}$ & 3.94 & 2.12 & 3.07 & 3.07 & 3.85 & 2.59 & 2.20 & 3.57 & 4.29 & 3.59 & & \\
\hline $\mathrm{Cl}$ & n.a. & n.a. & n.a. & n.a. & n.a. & 0.02 & 0.03 & 0.02 & 0.06 & n.a. & & \\
\hline Sum & 96.31 & 95.11 & 94.99 & 94.71 & 94.84 & 94.43 & 94.61 & 95.94 & 96.00 & 95.97 & & \\
\hline
\end{tabular}

Sum adjusted for $0=\mathrm{F}+\mathrm{Cl}$. $\mathrm{FeO}_{\mathrm{T}}=$ total iron. (c),(r) = core and rim of phenocryst. $(\mathrm{g})=$ groundmass or microphenocryst. * biotite alteration after phlogopite - see text. $\dagger$ possible xenocryst - see text. n.a. not analyzed. 

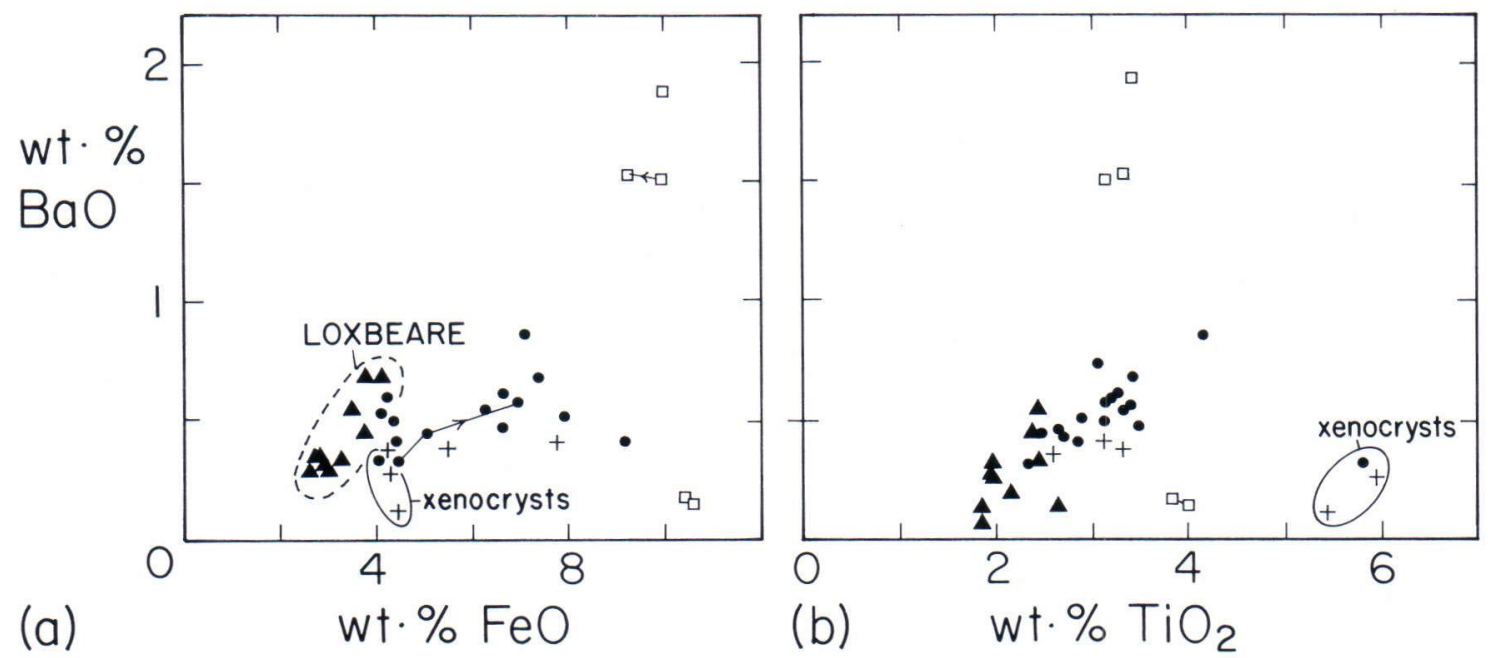

Fig. 2. $\mathrm{FeO}$ vs. $\mathrm{BaO}$ (a) and $\mathrm{TiO}_{2}$ (b) in micas. Symbols as in Fig. 1.

the same compositions, were reported by Mitchell (1981) for leucite lamproites from the West Kimberley area, Western Australia. The three phlogopites from the Hannaborough minette form a consistent group on Fig. 1, but have widely different $\mathrm{BaO}$ contents $(1.88$, $1.52-1.54,0.17-0.16$ ). Because this specimen is reddened and shows substantial alteration, no further analyses were made.

The remaining phlogopites show consistent chemical trends, which are partly represented

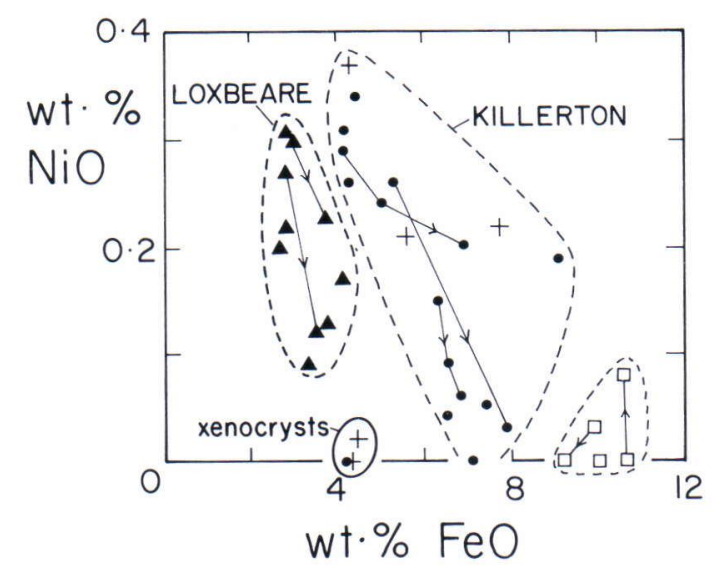

Fig. 3. FeO vs. NiO in micas. Symbols as in Fig. 1. by a core-rim relation in a single phenocryst. In detail, the Loxbeare and Killerton main-group phlogopites generate a single trend of $\mathrm{BaO} v s$. $\mathrm{TiO}_{2}$ (Fig. 2b) with the Loxbeare specimens having lower concentrations than the Killerton ones. On the plots involving total iron as $\mathrm{FeO}$, the Loxbeare phlogopites form a distinct trend at lower $\mathrm{FeO}$ than the Killerton ones. For kimberlitic micas such a displacement correlates with a presumed lower ferric/ferrous ratio (Smith, in preparation; $c f$. MARID micas,

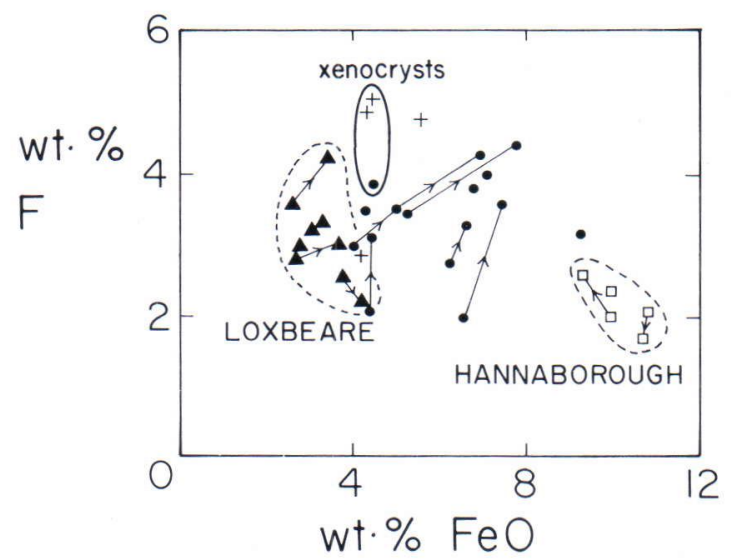

Fig. 4. FeO vs. $\mathrm{F}$ in micas. Symbols as in Fig. 1. 
Table 2. Analyses of diopside phenocrysts.

\begin{tabular}{|c|c|c|c|c|c|c|c|c|c|c|c|c|c|c|c|}
\hline & 1 & 2 & $3(\mathrm{c})$ & $3(r)$ & $4(c)$ & $4(c)$ & $4(r)$ & $5(c)$ & $5(\mathrm{r})$ & $6(x)$ & $6(x)$ & $6(r)$ & 7 & $8(c)$ & $8(\mathrm{r})$ \\
\hline $\mathrm{P}_{2} \mathrm{O}_{5}$ & n.a. & n.a. & 0.07 & 0.06 & n.a. & n.a. & n.a. & 0.03 & 0.05 & n.a. & n.a. & n.a. & n.a. & n.a. & n.a. \\
\hline $\mathrm{SiO}_{2}$ & 53.7 & 53.2 & 53.8 & 52.5 & 53.0 & 52.8 & 48.6 & 53.4 & 53.1 & 52.8 & 52.9 & 52.0 & 53.0 & 53.4 & 52.6 \\
\hline $\mathrm{TiO}_{2}$ & 0.0 & 0.0 & 0.32 & 0.30 & 0.2 & 0.0 & 0.8 & 0.31 & 0.35 & 0.0 & 0.0 & 0.0 & 0.0 & 0.0 & 0.2 \\
\hline $\mathrm{Al}_{2} \mathrm{O}_{3}$ & 2.8 & 2.5 & 1.62 & 1.70 & 2.5 & 2.5 & 5.3 & 1.45 & 1.63 & 2.0 & 1.7 & 3.3 & 2.2 & 2.6 & 2.8 \\
\hline $\mathrm{Cr}_{2} \mathrm{O}_{3}$ & 0.0 & 0.0 & 0.12 & 0.09 & 0.0 & 0.0 & 0.0 & 0.23 & 0.19 & 0.0 & 0.0 & 0.0 & 0.0 & 0.0 & 0.0 \\
\hline $\mathrm{FeO}_{\mathrm{T}}$ & 4.6 & 4.7 & 4.02 & 4.45 & 4.2 & 4.2 & 8.0 & 4.33 & 4.33 & 10.8 & 10.2 & 6.2 & 4.6 & 4.7 & 5.2 \\
\hline $\mathrm{MnO}$ & 0.0 & 0.0 & 0.12 & 0.10 & 0.0 & 0.0 & 0.0 & 0.12 & 0.16 & 0.6 & 0.6 & 0.0 & 0.0 & 0.0 & 0.0 \\
\hline $\mathrm{MgO}$ & 16.3 & 16.1 & 17.0 & 16.8 & 16.6 & 16.4 & 13.3 & 18.4 & 18.3 & 12.5 & 12.7 & 15.1 & 17.4 & 16.1 & 15.5 \\
\hline $\mathrm{NiO}$ & n.a. & n.a. & 0.07 & 0.01 & n.a. & n.a. & n.a. & 0.04 & 0.02 & n.a. & n.a. & n.a. & n.a. & n.a. & n.a. \\
\hline $\mathrm{CaO}$ & 22.8 & 22.5 & 22.5 & 22.3 & 22.4 & 22.4 & 23.6 & 21.5 & 21.3 & 21.6 & 21.5 & 23.3 & 21.4 & 22.3 & 22.3 \\
\hline $\mathrm{SrO}$ & n.a. & n.a. & 0.06 & 0.05 & n.a. & n.a. & n.a. & n.a. & 0.03 & 0.02 & n.a. & n.a. & n.a. & n.a. & n.a. \\
\hline $\mathrm{Na}_{2} \mathrm{O}$ & 0.2 & 0.2 & 0.38 & 0.44 & 0.3 & 0.5 & 0.3 & 0.38 & 0.37 & 0.7 & 0.4 & 0.0 & 0.0 & 0.0 & 0.4 \\
\hline $\mathrm{K}_{2} \mathrm{O}$ & 0.2 & 0.2 & 0.28 & 0.19 & 0.1 & 0.2 & 0.2 & 0.25 & 0.20 & 0.0 & 0.0 & 0.0 & 0.0 & 0.0 & 0.2 \\
\hline Sum & 100.6 & 99.4 & 99.06 & 100.29 & 99.3 & 99.0 & 100.1 & 100.47 & 100.02 & 101.0 & 100.0 & 99.9 & 98.6 & 99.7 & 99.2 \\
\hline $\mathrm{Ca}$ & 46.5 & 46.3 & 45.7 & 45.3 & 45.9 & 46.2 & 48.8 & 42.6 & 42.5 & 45.6 & 45.6 & 47.4 & 43.5 & 46.1 & 46.5 \\
\hline $\mathrm{Mg}$ & 46.2 & 46.1 & 48.0 & 47.6 & 47.3 & 47.0 & 38.3 & 50.7 & 50.8 & 36.7 & 37.5 & 42.7 & 49.2 & 46.3 & 45.0 \\
\hline $\mathrm{Fe}$ & 7.3 & 7.3 & 6.4 & 7.1 & 6.7 & 6.8 & 12.9 & 6.7 & 6.7 & 17.8 & 17.9 & 9.8 & 7.3 & 7.6 & 8.5 \\
\hline
\end{tabular}

$1-3,8286 ; 4-5,8287 ; 6,8288 ; 7-8,8290 . \mathrm{FeO}_{\mathrm{T}}=$ total iron. (c), (r) = core and rim of phenocryst. (x) = suggested xenocrystal core. n.a. not analyzed. Zr below detection where analyzed. 
Dawson and Smith, 1977); but see the Discussion.

All micas are rich in fluorine (Fig. 4), and some would qualify as fluorphlogopite. Whereas the micas from Czechoslovakian lamprophyres show a good negative correlation (Schulze et $a l$, in preparation) between $\mathrm{F}$ and both $\mathrm{Fe}$ and $\mathrm{Ti}$, as might be expected for simple crystalliquid differentiation, the Devon micas show a confusing set of data. Although there is a weak negative correlation between $\mathrm{F}$ and total iron (Fig. 4) for the entire group of data, there is a tendency for $\mathrm{F}$ to increase from core to rim. All the Devon micas contain more F (1.7-5.0 wt. \%) than groundmass micas from kimberlites (0.6-0.9 wt.\%, Smith et al. 1981) and the micas from the Navajo minettes $(0.1-1.1$ wt.\%, Jones and Smith 1981). Chlorine is higher in the Hannaborough micas $(0.13-0.29$ wt. \%) than the other Devon micas $(0.02-0.07$ wt. \%), and than the groundmass micas of kimberlites $(0.01-0.02$ wt. $\%)$, and than the groundmass micas of kimberlites $(0.01-0.02$ wt. \%) . So- dium is consistently lower in the Loxbeare micas $\left(0.03-0.20\right.$ wt. $\left.\% \mathrm{Na}_{2} \mathrm{O}\right)$ than the other Devon micas $\left(0.3-0.6\right.$ wt. $\left.\% \mathrm{Na}_{2} \mathrm{O}\right)$, while one high value (1.5) occurs in a Hannaborough mica.

Clinopyroxene. Fresh clinopyroxene occurs in the Killerton Park minettes, and pseudomorphs were found at Hannaborough. Clinopyroxene is abundant in Loxbeare breccias (Knill 1969), but was not found in our specimen.

Apart from one zoned rim and one xenocrystal core, it is all diopside (Fig. 5) and previous rock names referring to »augite» are misleading. $\mathrm{Na}_{2} \mathrm{O}, \mathrm{Al}_{2} \mathrm{O}_{3}$ and $\mathrm{TiO}_{2}$ are low $(<0.7$, $<3.3,<0.4 \mathrm{wt} . \%$, respectively) except for one zoned phenocryst rim which has higher $\mathrm{Al}$ and Ti (Table 2, analysis 4(c)). Both $\mathrm{Cr}_{2} \mathrm{O}_{3}$ and $\mathrm{NiO}$ are present in the WDS analyses of Mg-rich phenocrysts (to $0.23 \pm 0.03,0.07 \pm 0.04 \mathrm{wt} . \%$, respectively) and are probably present but below EDS detection in all of the grains. SrO is low (to $0.06+0.02$ wt. $\%$ ) but $\mathrm{K}_{2} \mathrm{O}$ is apparent-

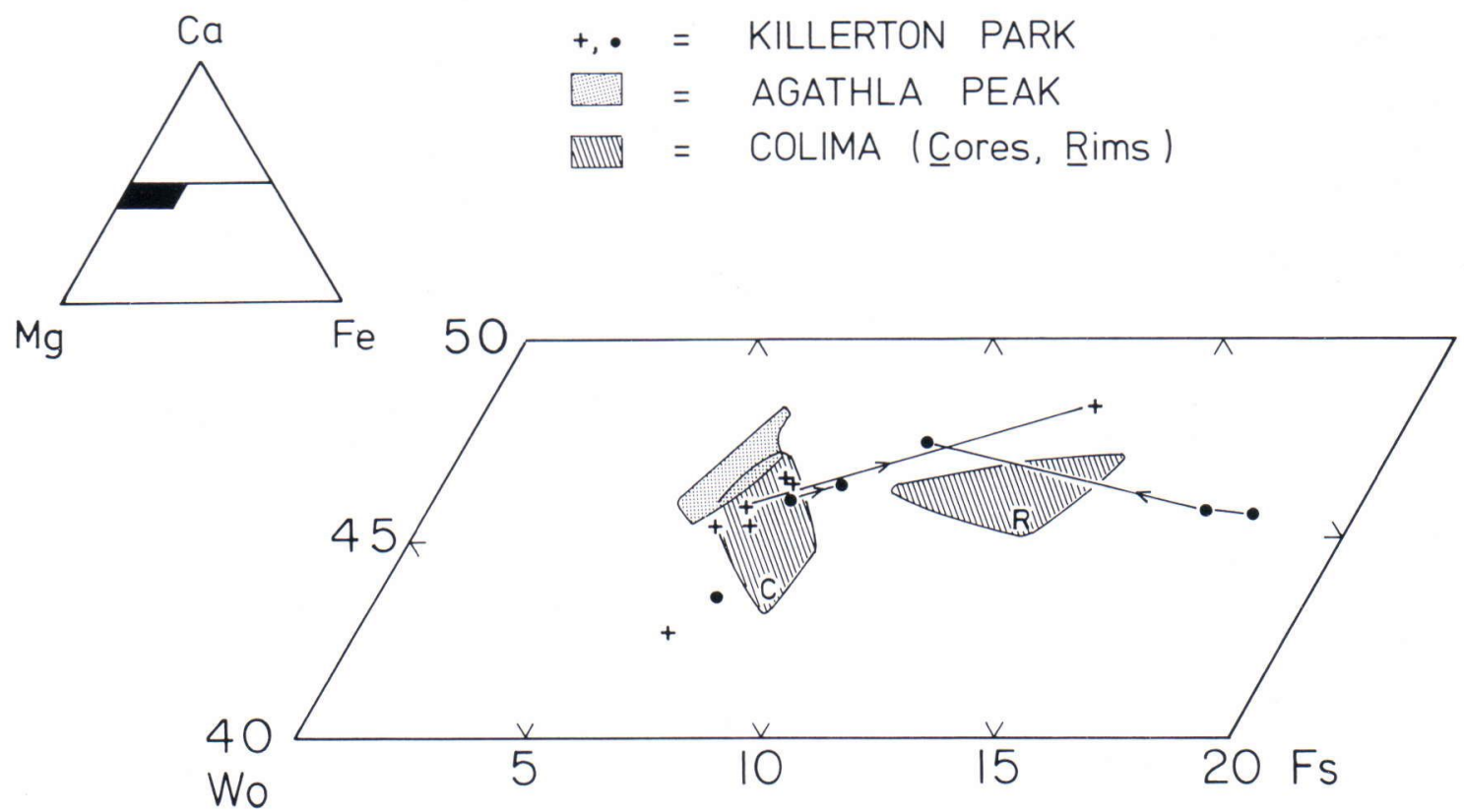

Fig. 5. $\mathrm{Ca}-\mathrm{Mg}-\mathrm{Fe}$ plot for clinopyroxenes. 
ly present in several grains (to $0.28 \mathrm{wt} . \%$ ); X-ray fluorescence from groundmass $\mathrm{K}$-feldspar is negligible since $\mathrm{K}_{2} \mathrm{O}$ decreases from core to rim of at least two individual grains (see Table 2). Killerton Park diopside is preferentially replaced by dolomite. Most phenocrysts are unzoned (Fig. 5; Ca-Mg-Fe) and zoning trends from core to rim are indicated by arrows. Some phenocrysts have normal zoning, and one xenocryst core is rimmed by diopside of normal composition.

Feldspar. Feldspar is freshest in the Killerton Park minettes, and consists of a fairly coherent group of sanidines (Fig. 6a). The groundmass laths contain significant $\mathrm{BaO}$ and $\mathrm{SrO}$ (up to 1.7 and 1.1 wt. $\%$ respectively; Table 3). Zoning was not detected because of the narrowness of the laths. The total analyzed range for the Killerton Park feldspars is from $\mathrm{Or}_{63}$ to $\mathrm{Or}_{82}$, with a tendency for An to decrease from approximately $\mathrm{An}_{6.5}$ to $\mathrm{An}_{5.0}$. A few grains of nearly pure orthoclase occur. Ferric oxide is substantial $(0.6-1.2 \mathrm{wt} . \%)$. Most values of $\mathrm{MgO}$ are less than $0.1 \mathrm{wt} . \%$, and higher values may result from overlap onto secondary dolomitic carbonate in the groundmass.

Minette from Hannaborough is severely altered, and most feldspar is replaced by carbonates and some zeolitic material. In addition, the remaining feldspar laths appear to have been strongly albitised, and few analytical totals are reasonable (Table 3): thus, feldspar laths from the Hannaborough sample (Fig. 6b) plot away from the locus of Killerton Park feldspar
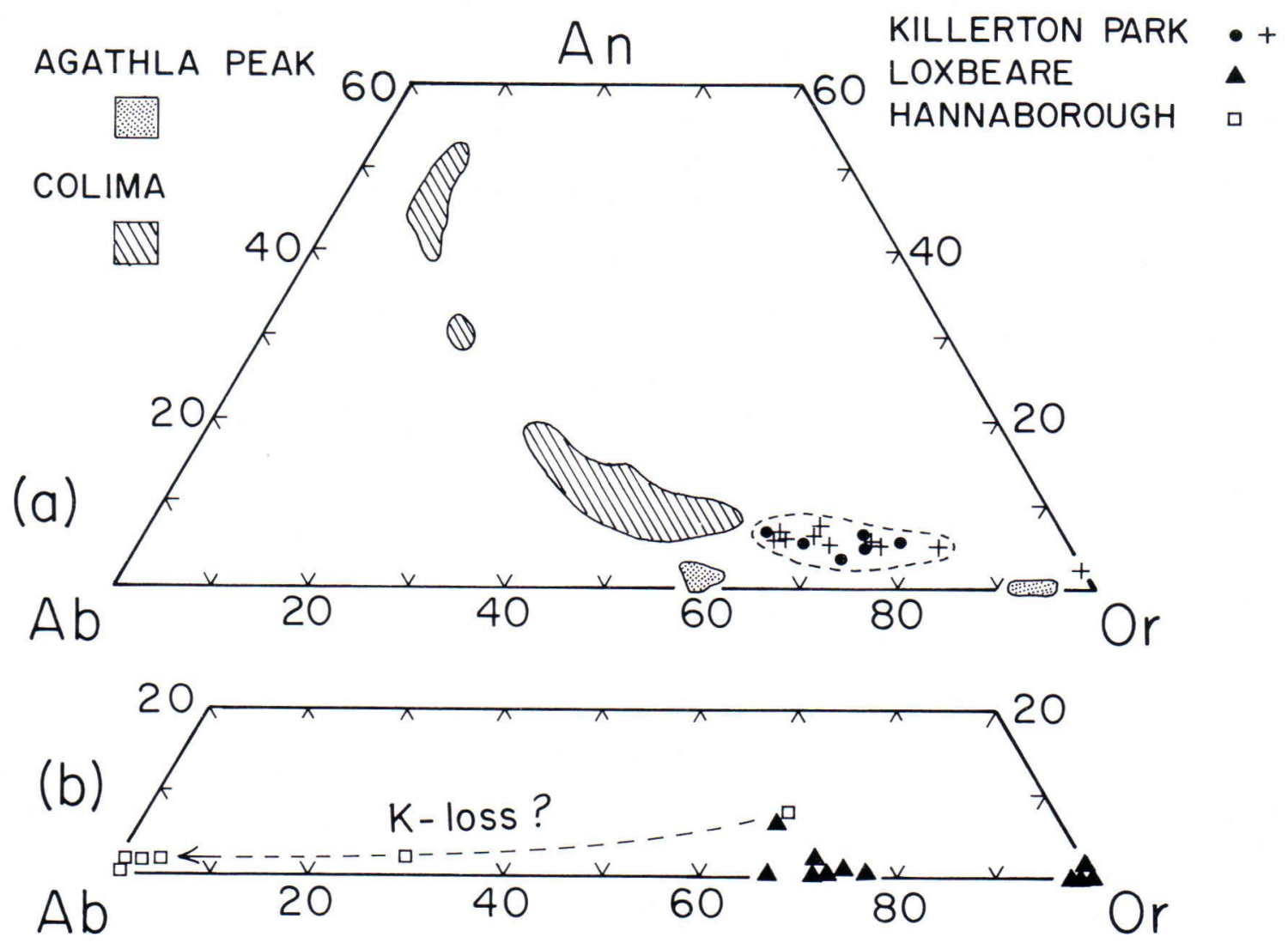

Fig. 6. Anorthite-albite-orthoclase plot for feldspars. 
towards the $\mathrm{Ab}$ apex. Most feldspars from the Loxbeare sample are very small laths, of compositions comparable to Killerton Park but with lower $\mathrm{Ca}$ content. Nearly pure K-feldspar occurs as larger grains or in alteration rims to quartz xenocrysts.

Overall, the Killerton Park feldspars, and the few freshest relic laths from both Hannaborough and Loxbeare, probably represent compositions closest to those crystallized from the minette magmas. The nearly pure K-feldspars and albites are interpreted as xenocrysts and metasomatic products, respectively.

Apatite. Although zoning was not detected, even in large phenocrysts $(>0.2 \mathrm{~mm}$ ), the rare earth oxides $\left(\mathrm{RE}_{2} \mathrm{O}_{3}\right)$ and $\mathrm{SrO}$ vary between different grains within individual samples from Killerton. Thus, total $\mathrm{RE}_{2} \mathrm{O}_{3}$ varies from 0.5 to 1.4 wt. $\%$ and $\mathrm{SrO}$ from 0.56 to 1.2 in sample 8287 (Table 4). The light REE enrichment, nor-

Table 3. Feldspar analyses.

\begin{tabular}{lcccccccccrrr}
\hline \multicolumn{3}{c}{ Hannaborough } & \multicolumn{3}{c}{ Killerton Park } \\
\hline $\mathrm{SiO}_{2}$ & 67.8 & 66.4 & 65.1 & 64.5 & 62.8 & 63.6 & 62.7 & 64.5 & 65.7 & 65.7 & 63.8 \\
$\mathrm{Al}_{2} \mathrm{O}_{3}$ & 19.7 & 20.6 & 19.6 & 19.4 & 18.6 & 19.3 & 19.5 & 18.5 & 17.5 & 17.7 & 17.9 \\
$\mathrm{FeO}_{\mathrm{T}}$ & 0.4 & 0.0 & 0.95 & 0.56 & 0.77 & 0.58 & 0.73 & 0.79 & 0.0 & 0.9 & 0.5 \\
$\mathrm{MgO}$ & n.a. & n.a. & 0.20 & 0.06 & 0.03 & 0.01 & 0.10 & 0.04 & n.a. & n.a. & n.a. \\
$\mathrm{CaO}$ & 0.3 & 0.5 & 0.83 & 1.04 & 1.11 & 1.01 & 0.66 & 1.14 & 0.5 & 0.5 & 0.0 \\
$\mathrm{BaO}$ & n.a. & n.a. & 0.36 & 0.38 & 0.69 & 1.68 & $0.62 *$ & 0.64 & n.a. & n.a. & n.a. \\
$\mathrm{SrO}$ & n.a. & n.a. & 0.37 & 0.82 & 1.11 & 1.14 & 0.38 & 0.93 & n.a. & n.a. & n.a. \\
$\mathrm{Na}$ & 11.2 & 7.5 & 1.78 & 2.85 & 3.21 & 2.80 & 2.72 & 3.02 & 3.5 & 3.0 & 0.3 \\
$\mathrm{~K}_{2} \mathrm{O}$ & 0.1 & 4.7 & 10.3 & 9.93 & 10.7 & 10.8 & 12.2 & 10.2 & 11.9 & 12.0 & 16.7 \\
\hline $\mathrm{Sum}$ & 99.5 & 99.7 & 99.49 & 99.54 & 99.02 & 100.92 & 99.05 & 99.76 & 100.1 & 99.8 & 99.3 \\
\hline $\mathrm{An}$ & 1.4 & 2.5 & 5.1 & 5.8 & 5.6 & 5.3 & 3.3 & 6.0 & 6.8 & 2.5 & 0.0 \\
$\mathrm{Ab}$ & 98.3 & 69.0 & 19.7 & 28.6 & 29.6 & 26.8 & 24.5 & 29.1 & 28.8 & 26.8 & 2.9 \\
$\mathrm{Or}$ & 0.3 & 28.5 & 75.2 & 65.6 & 64.8 & 67.9 & 72.2 & 64.9 & 64.3 & 70.7 & 97.1 \\
\hline
\end{tabular}

$\mathrm{FeO}_{\mathrm{T}}=$ total iron; multipy by 1.11 for ferric iron. n.a. not analyzed. ${ }^{*} \mathrm{BaO}$ particularly variable $(0.06-1.18)$.

Table 4. Apatite analyses.

\begin{tabular}{|c|c|c|c|c|c|c|}
\hline & 1 & 2 & 3 & 4 & 5 & 6 \\
\hline $\mathrm{P}_{2} \mathrm{O}_{5}$ & 55.9 & 55.2 & 54.6 & 55.2 & 55.3 & 53.8 \\
\hline $\mathrm{La}_{2} \mathrm{O}_{3}$ & 0.09 & 0.10 & 0.37 & 0.23 & 0.13 & 0.23 \\
\hline $\mathrm{Ce}_{2} \mathrm{O}_{3}$ & 0.24 & 0.25 & 0.73 & 0.48 & 0.25 & 0.49 \\
\hline $\mathrm{Pr}_{2} \mathrm{O}_{3}$ & 0.03 & 0.03 & 0.07 & 0.03 & n.a. & 0.06 \\
\hline $\mathrm{Nd}_{2} \mathrm{O}_{3}$ & 0.14 & 0.15 & 0.30 & 0.25 & 0.09 & 0.22 \\
\hline $\mathrm{Sm}_{2} \mathrm{O}_{3}$ & n.d. & n.d. & n.a. & n.a. & n.a. & 0.01 \\
\hline $\mathrm{Ge}_{2} \mathrm{O}_{3}$ & n.d. & n.d. & 0.03 & 0.02 & n.a. & 0.01 \\
\hline $\mathrm{Y}_{2} \mathrm{O}_{3}$ & 0.03 & 0.01 & 0.04 & 0.02 & 0.05 & 0.03 \\
\hline $\mathrm{CaO}$ & 38.0 & 40.2 & 40.7 & 40.5 & 39.4 & 39.0 \\
\hline $\mathrm{SrO}$ & 0.81 & 1.22 & 0.56 & 0.86 & 0.97 & 1.27 \\
\hline $\mathrm{F}$ & 3.77 & 4.75 & 4.53 & 4.52 & 3.54 & 4.27 \\
\hline $\mathrm{Cl}$ & 0.37 & 0.54 & 0.53 & 0.28 & 0.31 & 1.12 \\
\hline Sum & 97.71 & 100.33 & 100.43 & 100.44 & 98.48 & 98.46 \\
\hline
\end{tabular}

Sum adjusted for $0=\mathrm{F}+\mathrm{Cl}$. Er and $\mathrm{Yb}$ below detection in all analyses. 1, core of 0.25 mm phenocryst, 8287; 2, core of phenocryst, $8287 ; 3$, core of blunt prism, 8287,4 , core of prism, $8288 ; 5$, rim of euhedral phenocryst, $8289 ; 6$, core of $0.2 \mathrm{~mm}$ grain, 8285 . n.a. not analyzed. n.d. not detected. 
Table 5. Analyses of Fe-Ti oxides.

\begin{tabular}{|c|c|c|c|c|c|c|c|}
\hline \multirow[b]{3}{*}{ Sample } & \multirow{3}{*}{$\begin{array}{c}\text { Hannaborough } \\
1 \\
8285 \\
\end{array}$} & \multicolumn{2}{|c|}{ Killerton Park } & \multirow{3}{*}{$\begin{array}{c}4 \\
8290 \\
\end{array}$} & \multirow{3}{*}{$\begin{array}{c}5 \\
8288\end{array}$} & \multirow{3}{*}{$\begin{array}{c}6 \\
8287\end{array}$} & \multirow{3}{*}{$\begin{array}{c}7 \\
8288\end{array}$} \\
\hline & & 2 & 3 & & & & \\
\hline & & 8286 & 8287 & & & & \\
\hline $\mathrm{SiO}_{2}$ & 5.0 & 1.6 & 1.5 & 1.6 & 3.3 & 1.6 & 1.3 \\
\hline $\mathrm{TiO}_{2}$ & 1.5 & 16.7 & 17.4 & 15.5 & 3.3 & 1.7 & 49.7 \\
\hline $\mathrm{Al}_{2} \mathrm{O}_{3}$ & 2.6 & 1.9 & 2.1 & 1.6 & 1.7 & 5.6 & 2.9 \\
\hline $\mathrm{Cr}_{2} \mathrm{O}_{3}$ & 0.0 & 0.0 & 0.0 & 0.0 & 0.0 & 1.2 & 0.0 \\
\hline $\mathrm{Fe}_{2} \mathrm{O}_{3}$ & - & 33.2 & 32.1 & 35.4 & - & 54.3 & 5.4 \\
\hline $\mathrm{FeO}$ & 84.0 & 40.8 & 41.1 & 40.1 & 82.7 & 29.7 & 35.1 \\
\hline $\mathrm{MnO}$ & 0.0 & 0.0 & 0.0 & 0.0 & 0.0 & 2.1 & 0.0 \\
\hline $\mathrm{MgO}$ & 0.8 & 5.1 & 5.5 & 5.0 & 1.0 & 2.3 & 6.2 \\
\hline $\mathrm{CaO}$ & 0.0 & 0.2 & 0.0 & 0.0 & 0.4 & 0.0 & 0.1 \\
\hline $\mathrm{Na}_{2} \mathrm{O}$ & 0.4 & 0.0 & 0.0 & 0.0 & 0.0 & 0.0 & 0.0 \\
\hline $\mathrm{K}_{2} \mathrm{O}$ & 0.2 & 0.3 & 0.2 & 0.0 & 0.2 & 0.2 & 0.1 \\
\hline Sum & 94.5 & 99.8 & 99.9 & 99.2 & 92.6 & 98.7 & 100.8 \\
\hline
\end{tabular}

Iron oxides in magnetites calculated by method of Carmichael (1967). 1, altered magnetite (? goethite); 2-4, Mg-Timagnetite; 5, altered magnetite; 6, Al-Mn-magnetite; 7, Mg-ilmenite.

malized to chondritic abundances ( $c f$. Exley and Smith 1982), is consistent (Fig. 7), and similar to that of an apatite from the Pendennis minette. The Devon apatites are rich in $\mathrm{F}$ and $\mathrm{Cl}$, and the hydroxyl component must be small. Although pulse-height analysis was not used to resolve interferences from $\mathrm{P}$-satellite lines in the

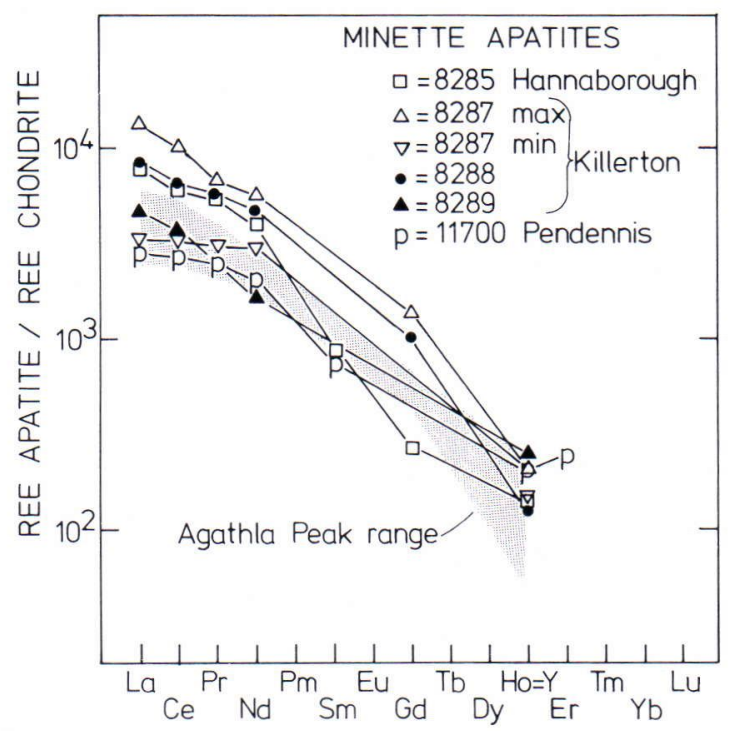

Fig. 7. Rare-earth profile, referenced to chondrites, for apatites. region of the F-peak, any systematic change in count rate should be similar for unknown and standard. The ratio $\mathrm{F} / \mathrm{Cl}$ varies in general from near 8 to 16 , but is substantially lower (4) in apatite from the Hannaborough sample.

Fe-Ti oxides. The freshest Fe-Ti oxides (Table 5) were found in the Killerton Park minettes. All grains occur in the groundmass, are of similar size, and fall into four categories: predominant $\mathrm{Mg}$-bearing titanomagnetite (MgO 4.85.4 wt.\%); Al-Mn-magnetite; altered magnetite, containing $\mathrm{SiO}_{2}$ and probably representing goethite; and rare Mg-ilmenite (6.2 wt.\% $\mathrm{MgO}$ ). Only magnetite or its altered relics (goethite?) was positively identified in the Hannaborough and Loxbeare samples.

\section{Discussion}

Comparison of the mineral compositions of the Devon minettes of Permian ages with those for younger minettes must take into account the textural evidence for contamination and alteration. Nevertheless, there are common features indicative of primitive liquids from the upper mantle. 
The Devon minettes have mineralogical features comparable with minettes from the Navajo volcanic field in southwestern U.S.A. (Jones and Smith 1983). In particular the mica is phlogopite and shows the typical rapid decrease in $\mathrm{Cr}$ and $\mathrm{Ni}$ with increasing $\mathrm{Fe}, \mathrm{Ti}$ and $\mathrm{Ba}$ (Figs. 1 and 2). The Loxbeare micas are unusual for their low iron contents and form a tight cluster in terms of $\mathrm{FeO}$ and $\mathrm{TiO}_{2}$ (Fig. 1). The variation of $\mathrm{BaO}$ with $\mathrm{TiO}_{2}$ is particularly interesting (Fig. 2b), and probably reflects a genuine fractionation trend in successive minette magmas. An even better correlation for these two oxides has been observed for minettes from Czechoslovakia (Schulze et al. in preparation). The anomalous variation of $\mathrm{BaO}$ with $\mathrm{TiO}_{2}$ in the mica of the Hannaborough minette (Fig. 2b) supports other mineralogical evidence for postigneous alkali-exchange and alteration. The iron-rich micas are associated with cleavage cracks in phenocrysts, and these biotites almost certainly represent secondary alteration of original phlogopite, although some irregularly intermixed phlogopite/biotite grains may represent altered biotite xenocrysts. Compared with micas from other minettes, the Devon samples are characterized by high halogen contents, and many of the phenocrysts are fluorphlogopites. The Hannaborough micas have high $\mathrm{Cl}$ and $\mathrm{Na}$, which is considered below with other evidence for metasomatism. Tidmarsh gave two bulk chemical analyses for micas from Loxbeare and Killerton Park (1932, p. 734) which agree well with our analyses. In particular, his value of 3.99 wt. \% $\mathrm{F}$ for Loxbeare mica falls in our range of $2.2-4.3$ wt.\% (Table 1). Particularly important are his high values for ferric iron (Loxbeare mica, $\mathrm{FeO}_{\mathrm{T}}=5.9$ wt.\%, $\mathrm{Fe}^{\mathrm{III}} / \mathrm{Fe}^{\mathrm{II}}$ $=1.1$; Killerton mica, his $\mathrm{FeO}_{\mathrm{T}}=13.1 \mathrm{wt} . \%$, $\mathrm{Fe}^{\mathrm{III}} / \mathrm{Fe}^{\mathrm{II}}=8$ ), which are consistent with the dark color of mica rims and groundmass grains. Because the correlation between total iron and $\mathrm{NiO}$ (see earlier) is suggestive of a low ratio of $\mathrm{Fe}^{\mathrm{III}} / \mathrm{Fe}^{\mathrm{II}}$ during crystallization, the possibility of post-crystallization oxidation should be considered.
Diopsidic clinopyroxenes have similar $\mathrm{Ca}-$ $\mathrm{Mg}$ - Fe ranges (Fig. 5) for minettes from Killerton Park, Colima (Luhr et al. 1981) and the Navajo volcanic field (Jones and Smith 1983). Some of the larger phenocrysts from Killerton Park show core-rim zoning to higher $\mathrm{Ca}$ and $\mathrm{Fe}$, and an unusual megacryst with reverse zoning probably has a xenocrystal core. Strontium is a typical minor constituent of diopsides from minettes.

Although many of the feldspar laths from the Devon minettes are $\mathrm{Na}$-bearing sanidines with similar compositions to those from the Navajo and Colima minettes (Fig. 6a), the albite and nearly pure K-feldspar are not magmatic. Postcrystallization ionic exchange of $\mathrm{Na}$ for $\mathrm{K}$ would explain the presence of albite and of Na-rich mica in the Hannaborough minette. Enrichment of $\mathrm{Cl}$ in the mica might have occurred during the same metasomatic events. Furthermore, is the high $\mathrm{Cl}$ content of Hannaborough apatites primary or secondary especially in view of their sometimes clouded appearance? The range of feldspar compositions in the Hannaborough minette (Fig. 6b) testifies against a xenocrystal origin of the albite, in spite of the presence of nearby granites. Because the anomalously K-rich feldspars from the Loxbeare minette are almost pure $\mathrm{KAISi}_{3} \mathrm{O}_{8}$, it seems likely that they are metasomatic products rather than xenocrysts from granites.

Although the apatites show a range in total REE and Sr contents, a chondrite-normalized REE plot (Fig. 7) shows similar light REEenrichment for all of the grains, which is comparable to that deduced for minette from Agathla Peak (Jones and Smith 1983). By contrast with Agathla Peak, there is no clear evidence for xenocrystal apatite. The curve for apatite (Jones and Smith unpublished data) from the Pendennis minette (Hall 1982), also from S. W. England, is included in Fig. 7 for comparison.

The ilmenite of the Killerton Park minette has 6 wt. \% $\mathrm{MgO}$ which lies in the range of 
5-23 wt. \% for ilmenite in kimberlites (Dawson 1980), and is indicative of crystallization from a primitive liquid. Furthermore, the higher content of $\mathrm{Al}_{2} \mathrm{O}_{3}(2.9$ wt. \%) in the Killerton Park ilmenite than for kimberlitic ilmenites $(<0.8$ wt.\%) is consistent with the higher $\mathrm{Al}$ content expected for a minette liquid than for a kimberlitic one.

To conclude, the mineral chemistry and textural relations of the Permian minettes from Devon indicate that post-crystallization alteration and metasomatism have not wiped out all the evidence for crystallization from primitive liquids similar to those of younger, less-altered minettes. Peridotite xenoliths in the Navajo minettes (Ehrenberg 1982) provide incontrovertible evidence for an upper-mantle origin of the minette magmas, and the similarity of

\section{References}

Bachinski, S. W. \& Scott, R B., 1979. Rare earth and other trace element contents and the origin of minettes (micalamprophyres). Geochim. Cosmochim. Acta, 43, 93100.

Cosgrove, M. E., 1972. The geochemistry of the potassiumrich Permian volcanic rocks of Devonshire, England. Contrib. Mineral. Petrol. 36, 155-170.

Dawson, J. B., 1980. Kimberlites and their Xenoliths. Springer, Berlin, 250p.

Dawson, J. B. \& Smith, J. V., 1977. The MARID (micaamphibole-rutile-ilmenite-diopside) suite of xenoliths in kimberlite. Geochim. Cosmochim. Acta, 41, 309-323.

Edmonds, E. A.\& 9 others, 1968. Geology of the country around Okehampton. Explanation of One-inch Geological Sheet 324, New Series. Institute of Geological Sciences, Her Majesty's Stationery Office, London.

Ehrenberg, S. N., 1977. The Washington Pass volcanic center: evolution and eruption of minette magmas of the Navajo volcanic field. Extended Abstracts, Second Int. Kimberlite Conf., Santa Fe, unpaged.

Ehrenberg, S. N., 1982. Rare earth element geochemistry of garnet lherzolite and megacrystalline nodules from minette of the Colorado Plateau province. Earth Planet. Sci. Letters, 57, 191-210.

Exley, R. A. \& Smith, J. V., 1982. The role of apatite in mantle enrichment processes and in the petrogenesis of phenocryst compositions between the Devon and Navajo minettes suggests that the Devon minettes also derive from the upper mantle. Although xenocrysts of quartz and possibly of $\mathrm{K}$-feldspar occur in the Devon minettes, there is no evidence that the nearby granites have a common chemical ancestor. Rather, it seems desirable to investigate a tectonic association between chemically independent sources of minettes and adjacent granites. This does not rule out an even earlier association between these independent sources.

Acknowledgements. We thank O. Draughn, R. Draus, I. M. Steele and N. Weber for technical help, and NSF EAR 82-06191 for financial support.

some alkali basalts. Geochim. Cosmochim. Acta, 46 , 1375-1384.

Hall, A., 1982. The Pendennis peralkaline minette. Mineral. Mag., 45, 257-266.

Jones, A. P. \& Smith, J. V., 1983. Petrological significance of mineral chemistry in the Agathla Peak and The Thumb minettes, Navajo volcanic field. J. Geol. 91, 643-656.

Knill, D. C., 1969. The Permian igneous rocks of Devon. Bull. Geol. Survey Great Britain, 29, 115-138.

Luhr, J. F. \& Carmichael, I. S. E., 1981. The Colima volcanic complex, Mexico: part II. Late Quaternary cinder cones. Contrib. Mineral. Petrol., 76, 127-147.

Mitchell, R. H., 1981. Titaniferous phlogopites from the leucite lamproites of the West Kimberley area, Western Australia. Contrib. Mineral. Petrol., 76, 243-251.

Nemec, D., 1972. Micas of the lamprophyres of the Bohemian Massif. Neues Jb. Mineral. Abh. 117, 196-216.

Rock, N. M. S., 1977. The nature and origin of lamprophyres: some definitions, distinctions, and derivations. Earth Sci. Reviews, 13, 123-169.

Roden, M. F., 1981. Origin of coexisting minette and ultramafic breccia, Navajo volcanic field. Contr. Mineral. Petrol, 77., 195-206.

Smith, J. V.; Delaney, J. S.; Hervig, R. L. \& Dawson, J. $B ., 1981$. Storage of $\mathrm{F}$ and $\mathrm{Cl}$ in the upper mantle: geochemical implications. Lithos, 14, 133-147.

Tidmarsh, W. G., 1932. The Permian lavas of Devon. Quart. J. Geol. Soc., 88, 712-775. 
102 Adrian P. Jones and Joseph V. Smith

Velde, D., 1969. Les micas des lamprophyres: kersantites, minettes, et lamproites. Bull. Soc. Franc. Min. Crist. 92, 203-223.
Velde, D., 1971. A note on an analcite-bearing lamproite from Devonshire. Geol. Mag. 108, 201-204. 